\title{
Somut Olmayan Kültürel Miras Kapsamında Arguvan Türkülerinin İçerik Analizi ${ }^{1}$
}

\author{
DOI: 10.26466/opus.817644
}

\author{
Ülkü Akkuş* - Gülșah Akkuș ** \\ * Öğr.Gör., İnönü Üniversitesi, Güzel Sanatlar ve Tasarım Fakültesi, Malatya/Türkiye \\ E-Posta: ulku.akkus@inonu.edu.tr ORCID: 0000-0001-5142-0791 \\ ** Dr. Öğr. Üyesi, İzmir Kâtip Çelebi Üniversitesi, Turizm Fakültesi, İzmir/Türkiye \\ E-Posta: gulsah.akkus@ikcu.edu.tr ORCID: 0000-0003-0263-8609
}

Öz

Yeryüzünde insanlığın binlerce yılda yarattı̆̆ı ve günümüze kadar ulaşan kültürün somut olmayan boyutunu ifade eden somut olmayan kültürel miras kavramı, 2003 yılında UNESCO tarafindan kabul edilen ve insanlı̆̆ın geçmişten günümüze taşıdığı kültür birikimlerinin korunmasını ve gelecek kuşaklara aktarılmasını amaçlayan Somut Olmayan Kültürel Mirasın (SOKÜM) Korunması Sözleşmesi ile önem kazanmaya başlamıştır. 2006 yılında bu sözleşmeye imza atan Türkiye, iki çeşit ulusal envanter düzenlemektedir; SOKÜM Ulusal Envanteri bunlardan biridir. 13 Mart 2013 tarihinde SOKÜM Ulusal Envanteri'ne 01.0021 sayı numarası ile kayıtlanan Arguvan Türküleri; Türk halk müziği içerisindeki yeri ve konumu, türkülerin kendine has yorumlama teknikleri, müzikal icrası, dil ve ağız özellikleri ile kültürel miras unsuru olarak belgelenmiştir. Bu çalışmada Arguvan türkülerinin, SOKÜM Ulusal Envanteri'nde yer almasını sağlayan kültürel özelliklerinin neler olduğunu tespit etmek ve UNESCO koruma listesine alnmasina gerekçe oluşturmak amaçlanmaktadır. Bu çalışmada derlenerek notaya alınmış ve çeşitli kaynaklardan ulaşılan 155 Arguvan türküsü incelenmiştir. Öncelikle biçimsel açıdan sıklık analizi ile değerlendirilen türküler; gerçekleştirilen içerik analizi sonucunda yirmi farklı kategoride toplanmıştır.

Anahtar Kelimeler: Somut Olmayan Kültürel Miras (SOKÜM), Arguvan Türküleri, Içerik Analizi, UNESCO.

\footnotetext{
${ }^{1}$ Bu çalışma, 4-6 Nisan 2019'da III. Uluslararası Uygulamalı Sosyal Bilimler Kongresi'nde (CIASOS) bildiri olarak sunulmuştur.
} 


\title{
Content Analysis of Arguvan Folk Songs as an Intangible Cultural Heritage
}

\begin{abstract}
The concept of intangible cultural heritage, which expresses the intangible dimension of the culture that has been created by humanity in thousands of years and has survived until today has started to gain importance with the Convention for the Safeguarding of the Intangible Cultural Heritage (ICH) adopted by UNESCO in 2003, aiming to preserve the cultural heritage of humanity from past to present and transfer them to future generations. Turkey, signed in this convention in 2006, organizes two types of national inventory; the National Inventory of ICH is one of them. The Arguvan folk songs recorded on the March 13th, 2013 with the number 01.0021 in the Turkish National Inventory, have been documented as the cultural heritage, language and dialect features and cultural heritage elements of Turkish folk music. This study aimed to determine the cultural characteristics of Arguvan folk songs and provide basis for safeguard listing of UNESCO. In this study, 155 Arguvan folk songs which were compiled and obtained from various sources, were examined. The folk songs, which were evaluated primarily by frequency analysis, were grouped in twenty different categories as a result of the content analysis.
\end{abstract}

Key Words: Intangible Cultural Heritage (ICH), Arguvan Folk Songs, Content Analysis, UNESCO. 


\section{Giriş}

Türküler toplumsal yapıyı çözümleyebilmek adına önemli sözlü kültür verilerindendir; halkın ortak duygu, düşünce dünyasının ve yaşam şeklinin kültürel motiflerle kendi bağlamında söz ile dokunarak, ezgisel bir yapı içinde seslendirilmesiyle oluşan bir bütündür. Bir yandan kültürün devamlılığını sağlarken, diğer yandan sosyo-tarihsel, sosyokültürel ve coğrafik yapısını ortaya koyar. Sezar, Roma İmparatorluğunun başındadır. Roma'ya bağlı iki küçük ülke yan yanadır. Bu ülkelerden biraz büyük olan ülkenin temsilcileri, Sezar'a giderek, öteki ülke halkının kendilerine katılmasını istemektedirler. Sezar, sonucu bildirmek için bir süre sonra gelmelerini ister. Ülkelere gönderdiği müfettişlere iki küçük ülkenin türkü kültürünü incelettiren Sezar, kararını verir; iki ülke halkının dilleri yakın olmakla birlikte, türküleri her bakımdan ayrı niteliktedir. Onun üzerine gelenlerin isteklerini kabul etmez (Öztelli, 1972, s.11). Bu bağlamda türkülerin ezgisel yapısı kadar, sözel yapısının da çözümlenmesi, kültürel çalışmalar açısından önem taşımaktadır.

Kültürlerin somut olmayan alanına giren ve halk müziği ürünlerinden olan türküler, toplumların tarihsel sürecinde geçmişten bugüne yaşanmışlıklarının ezgisel bir ifadesi olmuştur. Anadolu yüzyıllardır biriktirdiği türküleriyle oldukça zengindir (Akkuş ve Akkuş, 2018, s.392). Malatya'nın ilçelerinden biri olan Arguvan, adını türküleriyle özdeşleştirmiş; bu yörede üretilen türküler, Türk halk müziği literatürüne "Arguvan Türküleri" olarak girmiştir. Yöre türkülerinin ünü sınırlarının dışına çıkmış, dolayısıyla Anadolu coğrafyasında Arguvan türküleri adıyla anılır hale gelmiştir. İnançsal ve dünyevi alanlarda yayılım gösteren Arguvan türküleri gerek işlediği temaların zenginliği gerekse söyleyişteki dil yapısıyla kültürel bir farklılık arz etmektedir (Akkuş vd., 2014, s.655). 13 Mart 2013 tarihinde SOKÜM Ulusal Envanteri'ne 01.0021 sayı numarası ile kayıtlanan Arguvan Türküleri, kültürel miras unsuru olarak belgelenmiştir.

Somut Olmayan Kültürel Miras (SOKÜM) terimi, 2003 yılında UNESCO tarafından kabul edilen Somut Olmayan Kültürel Mirasın Korunması Sözleşmesi'nde kullanılmıştır. Bu sözleşmenin "Tanımlar" başlığını taşıyan ikinci maddesinde SOKÜM, "toplulukların, grupların 
ve kimi durumlarda bireylerin, kültürel miraslarının bir parçası olarak tanımladıkları uygulamalar, temsiller, anlatımlar, bilgiler, beceriler ve bunlara ilişkin araçlar, gereçler ve kültürel mekânlar" olarak tanımlanmıştır (UNESCO, 2003, Md.2). 2006 yılında yürürlüğe giren SOKÜM'ün Korunması Sözleşmesi, “insanlığın yüzlerce hatta binlerce yılda yarattığı ve sözlü kültür ortamlarında kuşaktan kuşağa aktardığı geleneksel bilgilerin ve kültürlerin korunmasını ve gelecek kuşaklara aktarılmasını sağlamak, bu yöndeki çaba ve çalışmaları desteklemek ve daha önemlisi yok olmakta olan bu değerli bilgi, uygulama ve sanat alanlarına toplumların dikkatini çekmek gibi amaçlara sahiptir" (Oğuz, 2013, s.137). Kültürel varlıklar, öncelikle sözleşmeye taraf olan ülkelerin milli listelerine alınır. Sonrasında korunmaya değer olduğu belirlenen özgün kültürel varlıklar, UNESCO tarafından hazırlanan korunma listesine aktarılır. Sözlü gelenekler ve anlatımlar, gösteri sanatları, toplumsal uygulamalar, ritüeller ve şölenler, doğa ve evrenle ilgili bilgi ve uygulamalar, el sanatları geleneği bu sözleşmenin korumayı amaçladığı somut olmayan kültürel mirasın belirdiği alanlardır (Oğuz, 2013, s.64).

Türkiye 19 Ocak 2006 tarih ve 5488 sayılı SOKÜM'ün Korunması Sözleşmesi'nin Uygun Bulunduğuna Dair Kanun'la bu sürece dâhil olmuş; 27 Mart 2006 tarihinde ise resmen taraf olmuştur (AREGEM, t.y.a). SOKÜM Ulusal Envanteri, Somut Olmayan Kültürel Mirasın Korunması Sözleşmesi gereğince Türkiye'nin düzenlediği iki çeşit ulusal envanterden biridir. Türkiye'nin 2019 yılı sonu itibariyle on sekizi UNESCO İnsanlığın Somut Olmayan Kültürel Mirasının Temsili Listesi'nde (AREGEM, t.y.b), 112'si de SOKÜM Ulusal Envanteri'nde olmak üzere toplam 130 kültürel miras unsuru bulunmaktadır (AREGEM, t.y.c); bunlardan biri de 0021 kayıt numarasiyla Arguvan Türküleri'dir. Arguvan Türküleri, özgün kültürel özellikleri dolayısıyla 2013 yılında SOKÜM Ulusal Envanteri'ne alınmıştır (AREGEM, t.y.d). Yörenin ağız ve dil özellikleri, sıkça kullanılan ikilemeleri (yineleme), literatüre kazandırılmış 400'ün üzerinde katma sözleri ve kendine has söyleniş teknikleri, Arguvan Türkülerinin en belirleyici özellikleridir (Akkuş ve Akkuş, 2018, s.394). SOKÜM Ulusal Envanteri'ne kayıtlanmasına vesile olan bu belirgin özellikler, bu türküleri kendiliğinden korumayı ve yaşatmayı gerekli kılmaktadır. 
Bugüne kadar Arguvan kültürü ve müziğine dair yapılan araştırmalarda Arguvan türkülerinin, Türk Halk Müziği içerisindeki yeri ve konumu, türkülerin kendine has yorumlama teknikleri, müzikal icrası ile dil ve yöresel ağız özellikleri üzerinde durulmuştur (Şahin ve Özerol, 2004; Ataş, 2009; Bulgan, 2009; Eroğlu, 2011; Akkuş vd., 2014; Haşhaş vd., 2015). Bu çalışmada Arguvan türkülerinin, SOKÜM Ulusal Envanteri'nde yer almasını sağlayan kültürel özelliklerinin neler olduğunu tespit etmek ve UNESCO koruma listesine alınmasına gerekçe oluşturmak amaçlanmaktadır. Bu amaçla türkülerin içerisinde kullanılan kelimelerin özellikleri ve türleri, türkülerin içeriği, kültürel ögeleri, yöreye özgü kavramları, yöresel söylemleri, motif ve sembolleri tespit etmek suretiyle Arguvan yöresi halk kültürünün, türkülerdeki görünümü ortaya çıkarılmaya çalışılmıştır.

\section{Yöntem}

$\mathrm{Bu}$ araştırmada nitel araştırma yaklaşımı benimsenmiştir. Araştırma kapsamında ele alınan Arguvan türküleri, araştırmanın evrenini oluşturmaktadır. Yargısal örnekleme ile dördü basılı kaynak olmak üzere dokuz farklı nota arşivinden, toplamda 155 adet notaya alınmış Arguvan türküsüne ulaşılmıştır. Yararlanılan kaynaklar ve bu kaynaklardan alınan türkü sayıları Tablo 1'de verilmiştir. Örneklem olarak seçilen türkülerin incelenmesinde öncelikle Arguvan Türkülerinin SOKÜM Ulusal Envanterine girmesini sağlayan biçimsel kriterleri ortaya çıkarmak için türkülerin en belirgin özelliklerine yönelik olarak (bağlantı ve katmalar, tekrarlar/ikilemeler, deyim ve söylemler) yapılan sıklık analizinin ardından içerik analizi uygulanmıştır. İçerik analizinde toplanan verileri açılayabilecek kavram ve ilişkilere ulaşmak amaçlanmaktadır. Bu amaçla birbirine benzeyen veriler, kavramlar ve temalar çerçevesinde bir araya getirilerek yorumlanır (Yıldırım ve Şimşek, 2013, s.259). İçerik analizi kapsamında öncelikle kod listesi oluşturulmuş, sonrasında analiz edilen türküler açık kodlama ile tek tek kelime, anlam ve bağlam açısından sınıflandırılmıştır. Kavramlar, bir türküde ne kadar tekrar edilirse edilsin bir kez sayılmıştır. Böylece bir türküde birden fazla geçen kavramın, genel görünümü etkilememesi sağlanmaya çalışılmıştır. 
Tablo 1. Çalışmada kullanılan türkülerin alındığı kaynaklar

\begin{tabular}{ll}
\hline Kaynak & $\mathbf{n}$ \\
\hline Arguvan Ezgileri- 2 (1998) & 69 \\
Arguvan Ezgileri- 1 (1998) & 50 \\
Şahin ve Özerol (2004) & 15 \\
TRT Nota Arşivi & 11 \\
Ufuk Erbaş & 5 \\
Şahin (2017) & 2 \\
Türk Müzik Kültürünün Hafızası & 1 \\
Saz Kursu & 1 \\
Türkü Dostları & 1 \\
Toplam & 155 \\
\hline
\end{tabular}

\section{Bulgular}

\section{S1klık Analizi}

Arguvan Türkülerini biçimsel açıdan değerlendirmek üzere gerçekleştirilen sıklık analizi sonucunda elde edilen bulgular; bağlantı ve katmalar, tekrarlar/ikilemeler, deyim ve söylemler olmak üzere üç ayrı başlik altında sunulmuştur.

Bağlantı ve katmalar: Arguvan türkülerinde "katma" olarak da adlandırılan ve türkü içerisinde tekrar edilen kelime ya da kelime öbekleri Arguvan ağzı söylem biçiminin en temel özelliklerindendir. Türküleri söyleyenler tarafından nida edilen sözcük ya da söz kalıpları; unutma, yineleme, pekiştirme, hitap etme gibi nedenlerle söyleyiş zenginliği ve bütünsellik kazandıran sözcük, cümle/dize ya da dizeler biçimindedir. Bağlantılar/katmalar; türkü girişinde, dize ya da dörtlük başlarında, dizelerden/dörtlüklerden sonra, dizelerde, sözcükler arasında bulunur (Akkuş vd., 2014, s.663). Şahin vd. (2004, s.37-62) tarafindan toplam 460 katma derlenerek halkbilimi literatürüne kazandırılmıştır. Dolayısıyla Arguvan türküleri, bağlantılar/katmalar yönünden ülkemizde en zengin türküler olarak değerlendirilmektedir (Akkuş vd., 2014, s.664). İncelenen 155 Arguvan türküsü içerisinde bir, iki, üç, dört ve daha çok dizeli bağlantı ve katmaların genel toplamı 105'tir. Dolayısıyla bağlantıların/katmaların incelenen türkülerdeki sayısal çokluğu, varsıllığını doğrulamaktadır. 
Arguvan türkülerinde tespit edilen tek dizeli katmalar (86) Tablo 2' de sayılarıyla birlikte verilmiştir.

Tablo 2. Tek dizeli olan bağlantı ve katmalar

\begin{tabular}{|c|c|c|c|c|c|}
\hline Bağlantı- Katma & $\mathrm{f}$ & Bağlant1-Katma & $\mathbf{f}$ & Bağlantı-Katma & $\mathbf{f}$ \\
\hline Dost & 7 & Ben ölürüm naz etme & 1 & $\begin{array}{l}\text { Gurban olam } \\
\text { neydem }\end{array}$ & 1 \\
\hline Ölem & 7 & Canan & 1 & Gurban olam naz etme & 1 \\
\hline Aman aman & 6 & Dağlar aman aman & 1 & Gülüm & 1 \\
\hline Yar yar & 5 & Dağlar duman duman & 1 & Hayın & 1 \\
\hline Aman & 4 & De yeri yeri & 1 & Leylo leylo & 1 \\
\hline Gurban olam & 4 & Deloy deloy da deloy & 1 & Nazlı yar & 1 \\
\hline Neydem & 3 & Derdin bana ağlama & 1 & Neydem neydem & 1 \\
\hline Oy oy & 3 & Di get elin kızı senden yar molur & 1 & Oy oy gaderim & 1 \\
\hline Ölem ölem & 3 & Di yeri yeri & 1 & Oy oy neydem & 1 \\
\hline Dost dost & 2 & Diley diley & 1 & Oy oy oy beni & 1 \\
\hline Gurban & 2 & Diley diley diley & 1 & Ölem yar & 1 \\
\hline Kömür gözlüm & 2 & Diloy dağlar diloy & 1 & Suna boylum ağlama & 1 \\
\hline Sunam sunam & 2 & Elin gızı ağlama & 1 & Vah beni beni & 1 \\
\hline Aman aman aman & 1 & Eller & 1 & Vefasız yar & 1 \\
\hline Aman aman aman aman & 1 & Felek ben neydem & 1 & Ya dost, ya dost & 1 \\
\hline $\begin{array}{l}\text { Aman aman aman aman } \\
\text { aman aman }\end{array}$ & 1 & Gadanı alayım & 1 & Yar & 1 \\
\hline $\begin{array}{l}\text { Ben ölmezsem bu dert } \\
\text { beni öldürür }\end{array}$ & 1 & Gelele de gülüm gelele & 1 & & \\
\hline
\end{tabular}

Türkülerde tespit edinen iki dizeli katmalar (9) sayılarıyla birlikte Tablo 3'te verilmiştir.

Tablo 3. Iki dizeli olan bağlantı ve katmalar

\begin{tabular}{ll}
\hline Bağlantı-Katma & $\mathbf{f}$ \\
\hline Bugün yine, bugün yine / Sen gidersen uğur olsun & 1 \\
Dağlar gı̧ımış / Yolcum üşümüş & 1 \\
Dağlar pareli / Açma yaremi & 1 \\
Di yeri yeri / Hayın yeri yeri & 1 \\
Diley diley diley aman / Diley diley yandım aman & 1 \\
Eylen güzel, eylen güzel / Ben de gelem & 1 \\
Gelin oy, gelin oy, gelin oy oy oyy / Yandı yürek derin oy oy oyy & 1 \\
Hamazlar hamazlar / O yar ilen oynamaya gomazlar & 1 \\
Nettim size verin benim yârimi / Nettim size beni yâre götürün & 1 \\
\hline
\end{tabular}

İncelenen türkülerde tespit edilen üç dizeli katmalar (5) Tablo 4'te sayılarıla birlikte verilmiştir. 
Tablo 4. Üç dizeli olan bağlantı ve katmalar

\begin{tabular}{ll}
\hline Bağlantı-Katma & f \\
\hline Beni beni beni / Sevdalım beni / Belalım beni & 1 \\
Bu ne işimiş / Dağlar üşümüş / Süslüm üşümüş & 1 \\
Bu ne işimiş / Yolcum üş̌̈müş / Sunam üşümüş & 1 \\
Diloğ dağlar dıloğ / Dıloğ hancım dıloğ / Diloğ yolcum dıloğ & 1 \\
Dıloy dağlar dıloy / Dıloy yolcum diloy / Diloy hancım dıloy & 1 \\
\hline
\end{tabular}

İncelenen türkülerde tespit edilen dört dizeli (5) ve beş dizeli (1) katmalar Tablo 5'te sayılarıyla birlikte verilmiştir.

Tablo 5. Dört ve daha çok dizeli olan bağlantı ve katmalar

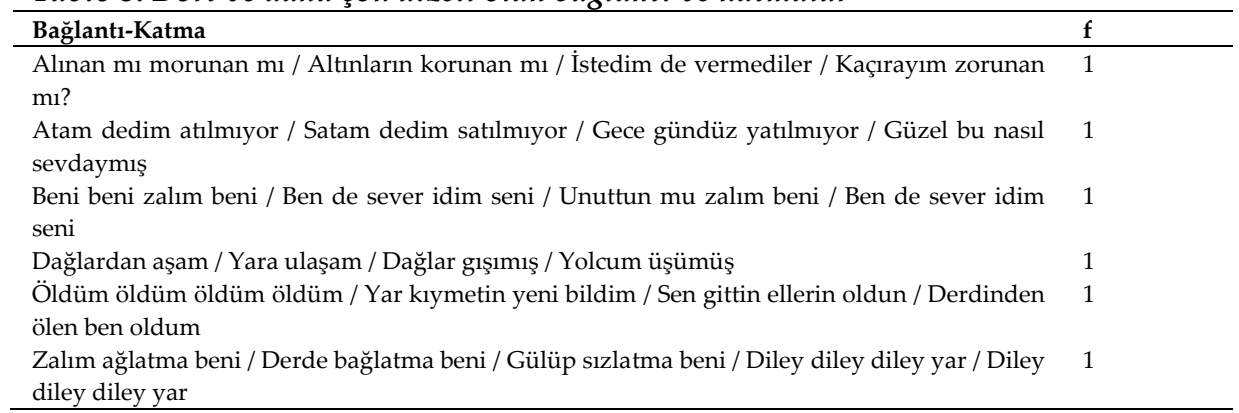

Tekrarlar/ikilemeler: Tekrarlar/ikilemeler Arguvan sözlü halk türkülerinin önemli özelliklerinden biridir. Tekrarlarda anlamı kuvvetlendirmek için bir sözcüğ̈un, aynen "yavaş yavaş, gide gide", z1t anlamıla "acı tatlı, düşe kalka", ilaveli "kapkara, mosmor", eş anlamlı "saç sakal, toz toprak" gibi biçimlerde kullanıldığı görülür. Arguvan türkülerinde sıklıkla görülen bu yapıyla duygu ve düşünceler daha kolay, anlaşılır ve samimi şekilde ifade edilir. Bu nedenle ikilemeler, Arguvan türkülerinin ifadesini güçlendiren önemli bir söylem biçimidir.

Arguvan türkülerinde zıt anlamlı, ilaveli ve eş anlamlı ikilemelerden ziyade aynen tekrarların (yavaş yavaş, dilinden dilinden) çok sık kullanıldığ1 görülür (Akkuş vd., 2014, s.663). Nitekim incelenen türkülerde tespit edilen toplam kırk altı ikilemenin kırk biri birer türküde, beşi ise ikişer türküde yer alarak bu oluşumu güçlendirmektedir (Tablo 6). 
Tablo 6. Tekrarlar/ikilemeler

\begin{tabular}{llll}
\hline Tekrar-İkileme & f & Tekrar-İkileme & f \\
\hline Ağlayı ağlayı & 2 & Gezer gezer & 1 \\
Bazı bazı & 2 & Gidem gidem & 1 \\
Dilinden dilinden & 2 & Gözlerin gözlerin & 1 \\
Elinden elinden & 2 & Gözleyi gözleyi & 1 \\
Perişan perişan & 2 & Havar havar & 1 \\
Ağlar ağlar & 1 & Hayın hayın & 1 \\
Bakar bakar & 1 & İsmini ismini & 1 \\
Beni beni & 1 & Meydanda meydanda & 1 \\
Bölük bölük & 1 & Narınan narınan & 1 \\
Çağlar çağlar & 1 & Ne fayda ne fayda & 1 \\
Çala çala & 1 & N'olur n'olur & 1 \\
Çalı mıyım çalı miyım & 1 & Oğlan oğlan & 1 \\
Dalgın dalgın & 1 & Öldürür öldürür & 1 \\
Dikiyi dikiyi & 1 & Ölümden ölümden & 1 \\
Divana divana & 1 & Özlerin özlerin & 1 \\
Dizleyi dizleyi & 1 & Sorun sorun & 1 \\
Doya doya & 1 & Söylerim söylerim & 1 \\
Duman duman & 1 & Sözlerin sözlerin & 1 \\
Efendim efendim & 1 & Terinen terinen & 1 \\
Eller eller & 1 & Ufak ufak & 1 \\
Eymir'in Eymir'in & 1 & Yakın yakın & 1 \\
Ezer ezer & 1 & Yavaş yavaş & 1 \\
Gezdim gezdim & 1 & Yorgun yorgun & 1 \\
\hline
\end{tabular}

Deyim ve söylemler (tamlama ve adlandırmalar): Şahin'e (2018) göre bir zekâ ürünü olan ve anlatıma akıcılık, çekicilik katan deyimler, genellikle somut benzetmelerden kurulur ve soyutu anlatır. Arguvan türkülerinde de deyim ve kalıp sözlerin yoğun biçimde yer aldığ görülür. Şahin ve Özerol (2004, s.235-269), Arguvan türkülerinde geçen 850'ye yakın deyim ve kalıp sözleri örnekleyerek işlemiştir. Arguvan türkülerinin doksan sekizinde deyim ve söylem bulunmaktadır. Tablo 7'de görüleceği üzere sayıca en çok yer alan söylemlerin başında sırasıyla on dört türküde geçen "nazlı yar", on türküde geçen "gurban olam", yedi türküde geçen "deli gönül" ve dört türküde geçen "zalımın gizı" ve "Hak vergisi" ile üç türküde geçen "dolu içmek" gelmektedir. Örneğin; Eğildim bir dolu içtim / Pirin elinden elinden; Sevince de deste baş1 sevmeli / Gurban olam Arguvan'li geline; sen de dersin benden başka yar yoktur / Gine deli gönül buldu bir tane, gibi. 
Tablo 7. Deyim ve söylemler

\begin{tabular}{|c|c|c|c|c|c|}
\hline Deyim - Söylem & $\mathbf{f}$ & Deyim-Söylem & $\mathrm{f}$ & Deyim-Söylem & $\mathrm{f}$ \\
\hline Nazlı yar & 14 & $\begin{array}{l}\text { Bir daha da düşmem senin } \\
\text { ardına }\end{array}$ & 1 & Kör olam & 1 \\
\hline Gurban olam & 10 & Bir olmak & 1 & Kör yılanlar soksun seni & 1 \\
\hline Deli gönül & 7 & Deli divane & 1 & $\begin{array}{l}\text { Meskenin cehennem yerin } \\
\text { har olsun }\end{array}$ & 1 \\
\hline Hak vergisi & 4 & Derdim ortağ & 1 & Meyil bağlamak & 1 \\
\hline Zalımın gizı & 4 & Dinsiz imansiz & 1 & Meyil vermek & 1 \\
\hline Dolu içmek & 3 & Divane gönlüm & 1 & Minnet eylemek & 1 \\
\hline Ah etmek & 2 & Gadan belan ben olam & 1 & Nazlı gül & 1 \\
\hline El vermek & 2 & Garip kalmak & 1 & Ömrün tükene & 1 \\
\hline Gadan alam & 2 & Gül yüzlüm & 1 & Sen de çek benden ötürü & 1 \\
\hline Kör olasın & 2 & Gün yüzlüm & 1 & Seyran etmek & 1 \\
\hline Murad almak & 2 & Güzel dost & 1 & Töremiyesin & 1 \\
\hline Yüz sürmek & 2 & Güzelliğin başının etini yesin & 1 & Tükenmez dert & 1 \\
\hline Ah çekmek & 1 & Hayırsız yar & 1 & Vadesi yetmek & 1 \\
\hline Aklını başından almak & 1 & İflah olmayasın & 1 & Vefasız güzel & 1 \\
\hline Ara ki bulasın beni & 1 & İkrar vermek & 1 & Viran olmak & 1 \\
\hline Arsız gönlüm & 1 & Kadir mevlam & 1 & Yolun olayım & 1 \\
\hline Ayan olmak & 1 & Kapı kapı dilene & 1 & Yüreğe dert olmak & 1 \\
\hline Bel bağlamak & 1 & Kimim var ki kime gidem & 1 & Zalım dert & 1 \\
\hline Bela bulmak & 1 & Kölen olayım & 1 & & \\
\hline
\end{tabular}

\section{İçerik Analizi}

Türkülerin kod listesi konular; özel isimler; dini unsurlar; zaman ve mevsimler; gökyüzü ve doğa unsurları, insan organları ve yüz hatlarl; dış mekân adları; geçiş dönemleri, akrabalık ve adlandırmalar; halk hekimliği ve tedavi unsurları; bayramlar, törenler ve inanışlar; formülistik sayılar; giyim eşyaları, takı ve çeşitli aksesuarlar; yapı malzemeleri; nesneler: eşya ve araç gereçler; sık kullanılan kelimeler adlandırmaları; yerleşim yeri adları; renk adları; hayvan adları; ağaç, çiçek ve bitki adları; yiyecek adları olmak üzere toplam yirmi maddeden oluşmaktadır (Tablo 8).

Tablo 8. İçerik analizi neticesinde ortaya çıkan kategoriler

\begin{tabular}{ll}
\hline Kategoriler & \\
\hline Konular & Formülistik Sayılar \\
Özel isimler & Giyim Eşyaları, Takı ve Çeşitli Aksesuarlar \\
Dini Unsurlar & Yapı Malzemeleri \\
Zaman ve Mevsimler & Nesneler: Eşya ve Araç-Gereçler \\
Gökyüzü ve Doğa Unsurları & Sık Kullanılan Kelimeler-Adlandırmalar \\
İnsan Organları ve Yüz Hatları & Yerleşim Yeri Adları \\
Diş Mekân Adları & Renk Adları \\
Geçiş Dönemleri, Akrabalık ve Adlandırmalar & Hayvan Adları \\
Halk Hekimliği ve Tedavi Unsurları & Ağaç, Çiçek ve Bitki Adları \\
Bayramlar, Törenler ve İnanışlar & Yiyecek Adları \\
\hline
\end{tabular}


Arguvan türkülerinin konuları: "Türküler ritmik ve melodik yapı analizi, ses alanı tespiti gibi pek çok incelemeye konu olabileceği gibi, konuları ve hikâyeleri açısından da geniş bir araştırma alanıdır. Türkülerde adı geçen motifler; gelişigüzel olmayan, bazı çağrışımları, özel anlamları bulunan ögelerdir. Bu anlamda söz konusu motiflerin saptanması ve incelenmesi büyük önem arz eder" (Vural ve Vural, 2013, s.645). Türküleri konularına göre gruplandırmak oldukça zordur. Türkülerin tek bir konuya bağlı kalmaması, örneğin bir türkünün ilk dörtlüğü ile ikinci dörtlüğünde geçen konuların farklı olması, türkülerin konularına göre tasnifini zorlaştırmaktadır. Ancak yine de bir türkünün konusuna yönelik ağır basan bir fikir bulmak olanaklıdır (Yücel, 2016, s.411). Bu çalışmada incelenen Arguvan türküleri; uzun yıllar Arguvan kültürü ve müziği üzerine çalışmalar yapan Antropolog Halkbilimci Hüseyin Şahin ile yapılan sözlü görüşmeler sonucunda, on iki ayrı başlık altında, Tablo 9'daki gibi sınıflandırılmıştır.

Arguvan türküleri içerikleri bakımından inançsal ve dünyevi olmak üzere iki alanda yayılım gösterir. Bunun nedeni Arguvan'ın, AleviBektaşi inancının yoğun olarak yaşandığı bir ilçe ve buna bağlı olarak Alevi-Bektaşi müziğinin temsil edildiği önemli yerleşim merkezlerinden olmasıdır (Akkuş vd., 2014, s.658). Tablo 2'de görülen inançsal içerikli dini müziklerin sayısal çokluğu bunu göstermektedir. Yörede "içeri makamı" olarak da adlandırılan Alevi-Bektaşilerinin inançsal müziği içerisinde incelenen otuz beş türkü; Semah, Deyiş, Tevhid, Duvaz-1 İmam, Mersiye türlerinden oluşmaktadır. Arguvan türkülerinin inançsal dini müziğinin dışında, yörenin ağız yapısıyla, dil özelliklerini yansıtan ve dünyevi konuların işlendiği türküler yörede "dışarı makamı" olarak bilinmektedir. Uzun havalar ve kırık havalardan meydana gelen bu türküler ağırlıklı olarak aşk, ayrılık, gurbet, sevda ve hasret gibi dünyevi konulardan oluşmaktadır. İncelenen türküler içerisinde en yoğun olarak sevda, aşk türküleri yer alırken bunları ayrılık ve hasret konuları takip etmektedir. Dert, sıkıntı, sitem konularını sırasıyla öğüt, yakınma, yakarma temalarının izlediği görülmektedir. Genel olarak bu türkülerin temalarına bakıldığında; farklı adlandırılsalar dahi pek çoğunun birbiriyle bağlantılı olduğu anlaşılır. Bir sevda varsa ayrılık kaçınılmazdır. Ayrılık, hasret çektirir. Hasret, dağlardan aşılmaz yol ise gurbet olur. İşte bu halkaların biraradalığında çekilenin adı derttir. Dert çoğu kez sitemle 
dillenir, bazen öğüt verir; bazen de kendine ya da kendi dışındaki canlılara yakını yakarır.

Tablo 9. Arguvan türkülerinin konularn

\begin{tabular}{llll}
\hline Türkülerin Konuları & f & Türkülerin Konuları & f \\
\hline Dini & 35 & Yakınma/Yakarma & 4 \\
Sevda & 29 & Ağıt & 2 \\
Aşk & 24 & Ah Etme/Eyleme & 2 \\
Ayrılık & 13 & Gurbet & 2 \\
Hasret & 13 & İş Türküsü & 2 \\
Dert, Sıkıntı & 12 & Askerlik & 1 \\
Sitem & 9 & Muhabbet & 1 \\
Öğüt & 5 & Oyun Türküsü & 1 \\
\hline
\end{tabular}

Özel isimler: Tablo 10 incelendiğinde; insanlık tarihinin ilk ismi Hz. Âdem'den, İslam dininin kurucusu Hz. Peygamberin soyunu temsil eden Hz. Ali ve Ehl-i beytin isimlerinin türkülerde hâkim olduğu görülür. Bu durum, Arguvan'da halkın inançsal boyutunun türkülerdeki önemli göstergelerindendir. Ayrıca Ferhat, Şirin, Leyla, Mecnun gibi halk hikâyeleri kahramanlarının isimleri de Arguvan sevda türkülerinin önemli örneklerindendir.

Tablo 10. Özel isimler

\begin{tabular}{llllll}
\hline Özel İsim & f & Özel İsim & f & Özel İsim & f \\
\hline Ali & 15 & Talip & 2 & Mihriban & 1 \\
Haydar & 7 & Veli & 2 & Musa & 1 \\
Mecnun & 6 & Ziya & 2 & Naki & 1 \\
Âdem & 4 & Bekir & 1 & Rıza & 1 \\
Arif & 2 & Bektaş & 1 & Selman & 1 \\
Canan & 2 & Celal & 1 & Serdar & 1 \\
Ferhat & 2 & Hasan & 1 & Şahin & 1 \\
Kerem & 2 & Hazar & 1 & Şirin & 1 \\
Leyla & 2 & İran & 1 & Taki & 1 \\
Süleyman & 2 & Kazım & 1 & & \\
\hline
\end{tabular}

Dini unsurlar: Tablo 11'de görüldüğü gibi Arguvan türkülerinde en fazla "Hak" motifi işlenmiştir. Onu sırasıyla Hz. Ali, Allah, Pir, Şah, Hz. Muhammed, Erenler, $\mathrm{Hu}$, Yemin, Mümin ad ve adlandırmaları takip etmektedir. Bu tabloda işlenen dini ögeler, yöredeki Alevi-Bektaşilerinin inançsal müziği içerisindeki Semah, Deyiş, Tevhid, Duvaz-1 İmam, Mersiye gibi türlerinde ağırlıklı olarak yer almaktadır. Dolayısıyla bu 
durum, Alevi-Bektaşi inanç kültürünün müzikteki görünümüne örneklenmesi bakımından önemlidir.

Tablo 11. Dini unsurlar

\begin{tabular}{llllllll}
\hline Dini Öge-isim & f & Dini Öge-isim & f & Dini Öge-isim & f & Dini Öge-isim & f \\
\hline Hak & 17 & Ayet & 2 & Hac & 1 & İmam Musa Kazım 1 \\
Ali & 16 & Azrail & 2 & Hacı & 1 & İmam Rıza & 1 \\
Allah & 10 & Cehennem & 2 & İlam & 1 & Kâbe & 1 \\
Pir & 8 & Dem & 2 & Bektaşi & 1 & Kıble & 1 \\
Şah & 7 & Enbiya & 2 & Mürteza & 1 & Mahşer & 1 \\
Erenler & 6 & Haram & 2 & Mansur & 1 & Mescit & 1 \\
Hu & 6 & Helal & 2 & Abdal & 1 & Peygamber & 1 \\
Muhammed & 6 & İbadet & 2 & Bismillah & 1 & Salavat & 1 \\
Mümin & 6 & İman & 2 & Cennet & 1 & Semah & 1 \\
Yemin & 6 & İmam & 2 & Dolu & 1 & Sırat Köprüsü & 1 \\
Secde & 4 & İmam Cafer & 2 & Elif & 1 & Sırat & 1 \\
Canlar & 3 & İmam Zeynel & 2 & Enel Hak & 1 & Şah Evliya & 1 \\
Cem & 3 & Kur'an & 2 & Evliya & 1 & Şah Hasan & 1 \\
Dört Kitap & 3 & Mehdi & 2 & Gülbenk & 1 & Şah Naki & 1 \\
Hacı Bektaşi & 3 & Mevla(m) & 2 & Himmet & 1 & Şah Taki & 1 \\
Veli & & & & & & Tanrı & 1 \\
Kırklar & 3 & Mezhep & 2 & Hüda & 1 & 1 \\
Melek & 3 & Muhammed Bakır & 2 & Hünkâr & 1 & Veysel Karani & 1 \\
Merdan Ali & 3 & Şah-1 Merdan & 2 & İmam Bakır-1 Cafer & 1 & Yüz sürmek & 1 \\
Şah Hüseyin & 3 & Tövbe & 2 & İmam Hasan & 1 & & \\
Zülfikar & 3 & Niyaz & 1 & İmam Hüseyin & 1 & &
\end{tabular}

Zaman ve mevsimler: Zaman ve Mevsimler ile ilgili kavramlar içerisinde en fazla kullanılan kelimenin "bugün” olduğu görülmektedir. Bugün kelimesi zamansal olarak içinde yaşanılan ânı karşıladığ 1 için önemlidir. Bu kelimeyi sırasıyla "gece, kış, yaz, sabah, akşam, gün, bir gün, dün, gece-gündüz, bir zaman, seher kelimeleri takip etmektedir. Karasal iklimin hüküm sürdüğü Arguvan'da geçiş mevsimlerinden ziyade kışın ve yazın mevsimsel olarak ağırlı̆̆ görülmektedir. Türkülerde mevsim, ay ve günlerin bölümlenmeleri, yerel adlandırılmaları da dizelerde kendine yer bulmuştur (Tablo 12).

Tablo 12. Zaman ve mevsimler

\begin{tabular}{llllll}
\hline Zaman-mevsim & f & Zaman-mevsim & f & Zaman-mevsim & f \\
\hline Bugün & 11 & İkindi & 2 & Er & 1 \\
Gece & 8 & Hayli zaman & 2 & Eski günler & 1 \\
Sabah & 6 & İkbahar & 2 & Ezel & 1 \\
Kış & 6 & Gündüz & 2 & Gün be gün & 1 \\
Yaz & 6 & Altı ay & 1 & Nevbahar & 1 \\
Akşam & 5 & Arada sırada & 1 & O günler & 1 \\
Gün & 5 & Ay & 1 & Seher vakti & 1
\end{tabular}




\begin{tabular}{llllll} 
Bir gün & 5 & Aylar yıllar & 1 & Sene & 1 \\
Dün & 4 & Bu ay & 1 & Seneler & 1 \\
Gece gündüz & 4 & Bu sene & 1 & Sonbahar & 1 \\
Bir zaman & 4 & Dakika & 1 & Yil & 1 \\
Seher & 3 & Devir & 1 & Yüzyıl & 1 \\
Bahar & 2 & Dün gece & 1 & & \\
\hline
\end{tabular}

Gökyüzü ve doğa unsurları: Türkülere genel olarak bakıldığında en çok işlenen gökyüzü ve doğa unsurlarının başında "dağlar" gelmektedir. Bu durum, Anadolu coğrafyasının yüksek ve dağlık yapısından kaynaklanmaktadır. Öte yandan Anadolu insanı geçmişten bugüne değin gündelik hayatın içinde dağları, gurbetin, kavuşamamanın, özlemin, ayrılık acısının zorunlu ve değişmez sorumlusu olarak konumlandırmış ve türkülerinde dile getirmiştir. Arguvan, denizden 1.150 metre yüksekliğiyle, engebeli ve dağlık bir yerleşime sahiptir. Bundan dolayı Arguvan türkülerinde en çok işlenen doğal özellik dağdır. Diğer yandan Arguvan, çok fazla göç veren bir ilçe olması nedeniyle türkülerinde işlediği gurbetin, ayrillı̆ın yegâne motifi de dağdır. Bununla birlikte, özel isim olarak türkülerde; Beydağı, Göldağı, Yıldız dağı ve Ayranca dağları da yer almaktadır. Diğer doğal özelliklere bakıldığında, dağları sırasıyla yayla, göl, çay, çöl, kaya, dere, yokuş ve ova takip etmektedir. Arguvan türküleri coğrafi açıdan ele alındığında; ilçenin dağlık yapısının yanı sıra Sarıçiçek, Gacer, Çakmak gibi yaylaları; Bemere deresi, Uludere, Şotik, Söğütlü, Avşar, Aliağa ve Morhamam çayları gibi önemli akarsuları; İsa köy göleti ve Karakaya baraj gölü bulunmaktadır. Yine Arguvan türkülerinde Fırat nehrinin adının da geçtiğini görüyoruz ki, "Suda boğulan Abdulkadir"in ardından yakılan türkü ve varyantlarında "Fırat" motifi çokça işlenmiştir. Dolayısıyla, Tablo 13'teki sayısal dağılım ile türkülerin sözel yapısı örtüşmektedir.

Sayısal olarak bakıldığında; türkülerde en çok geçen astronomi kelimesinin dünya olduğu görülmektedir. Kozmolojik unsurlardan $A y$, Güneş ve yıldız kimi zaman sevgi ve aşk türkülerinde sevgilinin güzelliğini betimlemek için kullanılmış; kimi zaman da ayrılık ve hasret türkülerindeki çaresizliği ifade etmiştir. Dünya, yaşama alanını, gerçek olanı yansıtmıştır. Doğa unsurlarından kar motifi sayısal olarak en fazla işlenen kelime olmuştur. Karasal iklimin hâkim olduğu Arguvan'da uzun ve sert geçen kış aylarının en önemli göstergesi olan kar, gündelik 
yaşamı etkileyen özelliğiyle doğal olarak türkülere de yansımıştır. Ancak bu tabloda farklı bir durum bulunmaktadır. Arguvan türkülerinde farklı isimlerle aynı doğa unsurunu anlatan yel, seher yeli, rüzgâr, deli poyraz, sam yeli, act poyraz, karayel, poyraz toplam yirmi yedi türküde yer almış ve on üç türküdeki kar motifini de geçerek en çok işlenen doğa olay1 olmuştur. Bu konuya ilişkin Arguvan Belediye Başkanı ile yapılan sözlü görüşmede; Arguvan'da rüzgârın kar yağışından daha etkili olduğu, hatta ilçenin yaz kış sürekli güçlü bir rüzgâr aldığı anlaşılmıştır (Mehmet, Kızıldaş, 16 Aralık 2019, Malatya). Rüzgârın, farklı adlarla Tablo 13'te görünen sayısal çokluğu da bunu teyit etmektedir.

Tablo 13. Gökyüzü ve doğa unsurları

\begin{tabular}{|c|c|c|c|c|c|}
\hline \multirow{2}{*}{$\begin{array}{l}\text { Gökyüzü ve Doğa } \\
\text { Unsurları }\end{array}$} & \multirow[b]{2}{*}{$\mathbf{f}$} & \multicolumn{2}{|c|}{ Gökyüzü ve Doğa Unsurları } & \multicolumn{2}{|l|}{ Gökyüzü ve Doğa } \\
\hline & & & $\mathbf{f}$ & Unsurları & $\mathrm{f}$ \\
\hline$\overline{\mathrm{Dağ}}$ & 36 & Gök & 3 & Göldağ & 1 \\
\hline Dünya & 14 & Kaya & 3 & Hava & 1 \\
\hline Kar & 13 & Acı poyraz & 2 & Kamer & 1 \\
\hline Yayla & 12 & Beydağı & 2 & Karahan Gediği & 1 \\
\hline Ay & 11 & Cihan & 2 & Karayel & 1 \\
\hline Yel & 10 & Deli poyraz & 2 & Nehir & 1 \\
\hline Göl & 8 & Dolu & 2 & Ova & 1 \\
\hline Güneş & 7 & Firat & 2 & Poyraz & 1 \\
\hline Çay & 6 & Sam yeli & 2 & Seher yıldızı & 1 \\
\hline Yildız & 6 & Soğuk & 2 & Taşkın & 1 \\
\hline Seher yeli & 5 & Yağmur & 2 & Tufan & 1 \\
\hline Çöl & 4 & Yokuş & 2 & Ülger & 1 \\
\hline Rüzgâr & 4 & Ayranca Dağları & 1 & Yeraltı & 1 \\
\hline Sel & 4 & Boran & 1 & Yıldız Dağ 1 & 1 \\
\hline Serin & 4 & Bulut & 1 & Zöhre yıldızı & 1 \\
\hline Dere & 3 & Burç yıldızı & 1 & & \\
\hline
\end{tabular}

İnsan organları ve yüz hatları: Arguvan türkülerinde insan organları ve yüz hatlarında; ilk sırada kırk üç türküde yer alan göz kelimesi gelmektedir (Tablo 14). İletişimin karşı ilk durağı göz, aynı zamanda sevda türkülerinde sevgiliyi aşk ateşine düşüren ilk organdır. Gözü dil takip eder ki, yine diyaloğun başlangıç noktası olan organ dildir. Yirmi türküde yer alan el, Arguvan'ın dünyevi türkülerinde sevgilinin eli olurken, inançsal türkülerinde ise tutulan Pir'in eli olmuştur. On yedi türküde geçen vücut organı baş, Arguvan inançsal türkülerinde "Can baş feda olsun ey sedribillah", diye yer alırken; dünyevi türkülerinde ise "Güzelliğin başının etini yesin" diye karşımıza çıkmaktadır. İnsan 
organları ve yüz hatlarının sayısal olarak fazla olmasının nedeni; Arguvan türkülerinin hem dünyevi hem de inançsal alandaki varlığı ile açıklanabilir. Çünkü organ ve yüz hatları; sevda, aşk türkülerinde sevgiliyi betimlemekteyken inançsal türkülerde özellikle inanç önderlerini betimler. Örneğin, "Yaktı yandırdı beni / Pir senin mah cemalin”, "Gül yüzlü efendim seyrana çıkmış" dizelerinde olduğu gibi.

Tablo 14. İnsan organları ve yüz hatları

\begin{tabular}{llllllll}
\hline İnsan vücudu & f & İnsan vücudu & f & İnsan vücudu & f & İnsan vücudu & f \\
\hline Göz & 43 & Akıl & 9 & Didar & 3 & Diz & 1 \\
Dil & 21 & Bel & 9 & Gerdan & 3 & Yan (böğür) & 1 \\
El & 20 & Saç & 8 & Kalp & 3 & Vücut & 1 \\
Baş & 19 & Yürek & 8 & Yanak & 3 & Deri & 1 \\
Yüz & 18 & Kol & 6 & Ser & 2 & Gamze & 1 \\
Kaş & 17 & Bağır & 6 & Koyun(döş) & 2 & Kil & 1 \\
Can & 15 & Ciğer & 5 & Alın & 2 & Ses & 1 \\
Zülüf & 15 & Omuz & 4 & Fikir & 2 & Dide & 1 \\
Gözyaşı & 14 & Ağı̈ & 4 & Dudak & 2 & Kirpik & 1 \\
Boyun & 13 & Göğüs & 4 & Kulak & 2 & Beden & 1 \\
Sine & 13 & Boy & 4 & Saçörgüsü & 2 & Benlik & 1 \\
Cemal & 10 & Ayak & 3 & Sırt & 2 & Esmeri & 1 \\
\hline
\end{tabular}

Dış mekân adları: İnsan yaşamının devam ettiği mekân ve yapılar hem çevresel betimlemede hem de betimlenen çevre içerisindeki yaşantıları ortaya koymak açısından ilgi çekici olmuştur. İncelenen Arguvan ezgilerinde en fazla geçen adlandırma konuları içerisinde pınar ve bă̆g (üzüm bağı/bahçe anlamında) öne çıkmaktadır (Tablo 15). "Pınarın yolunu cılga eylemiş.", "Pınar seni neydip neydip n'etmeli", dizelerinden hareketle; yar pinara giderken uzaktan bakmak ya da ona bir çift söz söylemek, işmar etmek için pınar, çeşme motifinin öne çıktığ görülmektedir. "Bağda bülbüller öter, güller açar; yine bülbül sesiyle, sevdanın rengi ve adı olan gül ile yâre seslenilir. Bahçe, gülşen (gül bahçesi) motifleri de aynı yönde türkülere girmiş adlandırmalardır. Diğer adlar/adlandırmalar değerlendirildiğinde ise; harman, ev, dam, kap önü, yol üstü, çayır/çimen, tarla, çarşı, avlu, hane, konak, köşk, oba, köy kelimelerinin de türkü metinlerinde kendisine yer bulduğu; hayatın akış1 içerisinde ilişkilerin, geçimin/geçimliğin, sevdanın, hasretin, dostluğun yaşandığ1 doğal ortamlar olduğu görülmektedir. Yine değirmen, mektep, han, meyhane gibi dış mekânlar türkü metni bütünlüğü içerisinde değerlendirildiğinde; yaşamın ekonomik, sosyal ve kültürel boyutlarının 
dizelere yansıdığı anlaşılmaktadır. Er meydanı, hem insanın yapmacıksız, dürüst, insani bakış gibi değerlerinin ortaya çıtığı deyim haline dönüşmüş bir kavram olarak yer alırken, hem de cem/meydan evinde yapılan ibadetler içerisinde yer alan on iki hizmetin yürütülmesinde yalansız, dolansız olmanın, hesap vermenin meydanı olarak karşımıza çıkmaktadır.

Tablo 15. Dış mekân adları

\begin{tabular}{llllll}
\hline Diş Mekân & f & Diş Mekân & f & Diş Mekân & f \\
\hline Bağ & 12 & Yol üstü & 3 & Değirmen & 1 \\
Pınar & 12 & Çayır & 2 & Han & 1 \\
Bahçe & 6 & Çimen & 2 & Hane & 1 \\
Ev & 5 & Dükkân & 2 & Kapının eşiği & 1 \\
Harman & 5 & Gülşen & 2 & Konak & 1 \\
Er meydanı (Cem evi) & 4 & Köy & 2 & Köşk & 1 \\
Dam & 3 & Su yolu & 2 & Mektep & 1 \\
Kale & 3 & Aktar & 1 & Meyhane & 1 \\
Kapı önü & 3 & Avlu & 1 & Oba & 1 \\
Pazar & 3 & Çarşı & 1 & Tarla & 1 \\
\hline
\end{tabular}

Geçiş dönemleri, akrabalık ve adlandırmalar: Anadolu halk kültüründe olduğu gibi özelde de Arguvan halk kültürü içerisinde geçiş dönemleriyle ilgili inanmalar ve uygulamalar önemli bir yer tutmaktadır. Bu da doğal olarak Arguvan türkülerine yansımaktadır. Geçiş dönemleri içerisinde doğum, sünnet, askere gitme, evlenme ve ölüm çizgisinde ortaya çıan olay ve olgular bir şekilde dizelerde kendisine yer bulmuştur. Tablo 16 incelendiğinde; en fazla ölüm (13) olgusuna değinildiği ortaya çımaktadır. Ölümle bağlantılı olarak felek, ömür, mezar, kader, fani dünya, kara toprak, fani, yalan dünya, kara kına, vadesi dolmak, kabir, ecel, yas, göç, kara yazı, alın yazısı, musalla, ahiri ölüm gibi yoğun bir kültürel geleneğin adlandırma ve söylemleri görülmektedir. Ölüm olgusunun feleğe sitemle ele alındığı, her şeyin alın yazısı ve kaderde olduğu bakışı; türkülerin dizelerinde karamsarlık olarak ortaya çıkmaktadır. Bu durum genelde daha çok sevdiğine kavuşamama ve hasretlikle ele alınmış bir bakış olarak karşımızda durmaktadır.

İncelenen türkü metinlerinde statü ve akrabalık bağlarına göre de yaşam içerisinde adlar ve adlandırmalara rastlamak mümkündür. Ana (4), baba (4), bacı (3), kız (4), gardaş (1) ve en çok da gelin (7) adlandırması bu anlamda öne çıkmaktadır. Aslında Arguvan türkülerine bütüncül 
bakıldığında; dize sonlarındaki katma ve yinelemelerde "ölüm senin elinden", anan öle", "bacın öle gardaş senin" gibi motiflerin sıkça kullanıldığ 1 görülmektedir. Arguvan yöresinde okunan bir deyişte ise yörede çok kullanılmayan bir adlandırmaya rastlarız; "içeri makamı" olarak da bilinen, Arguvan yöresinin inanca dayalı müzik kültüründe; yörenin önemli kaynak kişilerinden olan Cemal Erbek'ten derlenen bir deyişte (Temiz, 1998, s.124-130) müftü ve fetva ad ve adlandırmasının geçtiği görülür. Gençlik ile ilgili bakıldığında; askerlik, alay, gençlik gibi adlandırmalar ile evlenme geleneğine yönelik de gelin, eş, koca, kına, yuva, düğ̈̈n, bala (yavru/çocuk) gibi birincil derece akrabalık kavramlarının daha fazla olduğu ortaya çıar. Bu durum ben merkezli olmak yerine kolektivist bir kültürü paylaşan bireyin, sevinç ya da acısını, sevdasını, hasretliğini kimseyi üzmeden, sevdiklerine hissettirmeden kendi içerisinde yaşamak istemesinden kaynaklanıyor olabilir.

Tablo 16. Geçiş dönemleri, akrabalık ve adlandırmalar

\begin{tabular}{llllll}
\hline Geçiş Dönemleri & f & Geçiş Dönemleri & f & Geçiş Dönemleri & f \\
Ölüm & 13 & Kader & 3 & Gardaş & 1 \\
Felek & 9 & Fani & 2 & Gençlik & 1 \\
Gelin & 7 & Fani dünya & 2 & Göç & 1 \\
Ömür & 7 & Kara toprak & 2 & Kabir & 1 \\
Ana & 6 & Yalan dünya & 2 & Kara kına & 1 \\
Eş & 6 & Ahiri ölüm & 1 & Kara yazı & 1 \\
Kına & 5 & Alay & 1 & Kirve & 1 \\
Baba & 4 & Alın yazısı & 1 & Koca & 1 \\
Düşman & 4 & Asker & 1 & Musalla & 1 \\
Kız & 4 & Bala & 1 & Müftü & 1 \\
Mezar & 4 & Düğün & 1 & Vadesi dolmak & 1 \\
Oğlan & 4 & Ecel & 1 & Yas & 1 \\
Bacı & 3 & Fetva & 1 & Yuva & 1 \\
\hline
\end{tabular}

Halk hekimliği ve tedavi unsurlarn: Türkülerde geçen adlandırma ve adların bir bölümü hekimlik alanıla ilgili olsa da vurgulanmak istenen normal hastalık tedavisinden ziyade çoğu zaman aşk acısı, hasretlik ve sevda gibi motiflerle birlikte anılarak anlamlandırılmıştır (Tablo 17). Arguvan ve Sivas yöresinde sıklıkla okunan "Celaloğlan" türküsünde Celal'in nişanlısının yaktı̆̆ı ağıtın öyküsünde ince hastalığa/vereme yakalanıp ölen Celal ile ilgili birçok bilgi verilmektedir. "Arpalar destesiyem/Güzeller hastasıyam" söz başı ve devamında okunan dizelerin değerlendirilmesinde; burada Arguvan yöresi "ekin biçme/deme çevirme" türkülerine ait bir örnekte geçen bir güzele âşık 
olma, sevdalanma motifinin hasta olma adlandırmasıyla ilişkilendirilmesi görülmektedir. Yörenin önemli âşıklarından Seyit Meftuni (Âşık Mamo Temiz) bir deyişinde; "Seyit Meftuni'yem hayranım sana / Acı şu halime merhem et (ol) bana" derken merhem motifini hastalık sağaltma anlamında değil; yine "Bir tabip olup da gel sar yaremi" dizesinde de inanca dayalı tasavvufi anlamında kullandığı görülmektedir.

Tablo 17. Halk hekimliği ve tedavi unsurları

\begin{tabular}{llll}
\hline Halk hekimliği & f & Halk hekimliği & f \\
\hline Hasta & 3 & Şifa & 2 \\
Tabip & 3 & Doktor & 1 \\
Illaç & 2 & Sağlı & 1 \\
Merhem & 2 & Verem & 1 \\
\hline
\end{tabular}

Bayramlar, törenler ve inanışlar: Arguvan türkülerinde yer yer törenlere ve törenler içerisindeki uygulamalara ilişkin adlandırma ve tanımlamaların olduğunu görmek mümkündür. Tablo 18 incelendiğinde bayram (3) adının özellikle bayram öncesi arife günüyle birlikte ele alındığı izlenimi edinilebilir. "Aşağıdan gelir omuz omuza" söz başıyla başlayan ve TRT repertuarında 1.347 numarası ile yer alan türkünün öyküsü Arguvan Kızık köyünde (mahallesi) 1952 senesinde bayramı karşılama eğlentisinde geçen bir elim olayda Hıdır Hoca'nın ardından âşık Bektaş Kaymaz tarafından yazılan bir ağıtın ülke genelinde kırık hava olarak yaygınlaştığ1 da görülmektedir (Şahin ve Özerol, 2004, s.420).

Tablo 18. Bayramlar, törenler ve inanışlar

\begin{tabular}{llll}
\hline Bayram-Tören & f & Bayram-Tören & f \\
\hline Bayram & 3 & Kurban & 1 \\
Dilek & 3 & Mâni & 1 \\
Mihman & 3 & Muska & 1 \\
Nazar & 2 & Mübarek & 1 \\
Aht & 1 & Şehit & 1 \\
Bilmece & 1 & Uğur & 1 \\
\hline
\end{tabular}

Formülistik sayılar: Türk kültürü içinde taşıyıcı ve üretici niteliğiyle önemli yer tutan Alevi-Bektaşi kültürü, birtakım kavramlara simge değeri yüklemesi ile dikkat çeker ki bunlardan biri de sayılardır (Coşar, 2011, s.117). Arguvan yöresinde inanca dayalı müzik/içeri makamı kapsamı içerisinde deyişler, düvazlar, mersiyeler ve semahlar önemli bir 
yer tutar. Mesela sayıların formülistik açıdan değerlendirilmesine bir örnek olarak Kırklar motifinin doğması, alevi inancındaki "Kırklar meclisi" inancıyla ilgilidir; Alevi-Bektaşi inancına göre Tanrının yarattığ 1 kırk ermiş kişiden oluşan topluluğu ifade eder (Bozkurt, 1990, s.37).

Tablo 19'daki ad ve adlandırma motiflerine dair inançla ilgili birçok deyişte belirtilen adlandırma ve tanımlamaların geçtiği görülmektedir. Alevi-Bektaşi inancında dört kapının tasavvuftaki karşılığ "şeriat", "tarikat", "marifet" ve "hakikat" şeklinde sıralanan dört makamı ifade eder ki bunun da karşılığı her mertebede onar makamı temsil eden kırk makamdır. Alevi-Bektaşi ibadet veya cemlerinde "bism-i Şah, Allah Allah..." diye başlanarak okunan Gülbank/Gülbenklerde ${ }^{2}$ Üçlerin, Beşlerin, Yedilerin, Oniki İmamların, Kırkların diye devam eden ve birtakım sayılarla sembolize edilen ululardan bahsedilir. Bunlar AllahMuhammed-Ali üçlemesinden Ehl-i Beyit'i de simgeleyen sayılardır. Her biri altı binden yeryüzündeki üç tür canlıya ait olan, birbirinden ayrı olmayan ve tanrı ile kuşatılmış on sekiz bin âlemi karşılarken; Hoca Ahmet Yesevi'nin halifeleri olan "Horasan Erenleri"ni, "Türkistan Pirleri"ni doksan bin sayısı simgelemektedir (Günşen, 2007, s.338-345).

Tablo19. Formülistik sayılar

\begin{tabular}{llll}
\hline Formülistik Sayı & f & Formülistik Sayı & f \\
\hline Dört (kapı) & 3 & Beş & 1 \\
Yedi & 3 & Doksan bin & 1 \\
Yüz bin & 3 & İki & 1 \\
Kırklar & 2 & On beş & 1 \\
On dört & 2 & On sekiz bin & 1 \\
On iki & 2 & On üç & 1 \\
Yediler & 2 & Seksen bin (ayet) & 1 \\
Üç & 2 & Yüz & 1 \\
\hline
\end{tabular}

Giyim eşyaları, takı ve çeşitli aksesuarlar: Türkü geleneği içerisinde özellikle kadına dair giyim, süs eşyası gibi ziynet eşyalarının daha sıklıkla kullanıldığı görülmektedir. Örneğin kadına dair giyim eşyaları fistan, mendil, basma (kumaş), önlük, kutnu (kumaş), çeyiz, ipek mendil, esvap, terlik, dolak, puşu, taç, yazma, nakış, fes vb. adlar/adlandırmalar ve bu adlarla yapılan nitelemelerin yoğunluğu; özellikle erkek tarafından

${ }^{2}$ Gülbank/Gülbenk, Alevi-Bektaşi toplantı ve cem ayinlerinde, bütün canlar secdede iken, pir veya mürşidin yaptığı uzun duadır (Günşen, 2007, s.343). 
ve sevdalandığı, âşık olduğu kıza yakıldığını, giyimiyle, takısıyla övüldüğünü ya da betimlendiğini göstermektedir (Tablo 20).

Tablo 20. Giyim eşyaları, takı ve çeşitli aksesuarlar

\begin{tabular}{llllll}
\hline Giyim & f & Giyim & f & Giyim & f \\
\hline Altın & 4 & Önlük & 2 & İ̆ne iplik & 1 \\
Fistan & 3 & Aba & 1 & İpek mendil & 1 \\
Gömlek & 3 & Çorap & 1 & Maksi & 1 \\
Kemer & 3 & Çuha bezi & 1 & Nakış & 1 \\
Mendil & 3 & Dolak & 1 & Puşu & 1 \\
Sandık & 3 & Don & 1 & Taç & 1 \\
Basma & 2 & Döşek & 1 & Tarak & 1 \\
Cevahir & 2 & Duvak & 1 & Terlik & 1 \\
Çeyiz & 2 & Düğme & 1 & Yazma & 1 \\
Etek & 2 & Elbise & 1 & Yorgan & 1 \\
Kumaş & 2 & Esvap & 1 & Yün & 1 \\
Kutnu & 2 & Fes & 1 & Yüzük & 1 \\
\hline
\end{tabular}

Yapı malzemeleri: Yapı malzemelerinin de türkü metinlerine az da olsa girdiği anlaşılmaktadır (Tablo 21). En fazla taşın (5) kullanıldığı, sonrasında kum ve toprak (2), mermer (1) ve çimanto (1) adlandırmalarının geldiğini görüyoruz. "Celaloğlan" türküsünde "Celaloğlan hasta olmuş çimantoda yata yata" dizesi hem yapı malzemesi çimanto hem de yerel bir mevki ismi olarak karşımıza çıar. Arguvan yöresinde halay türküsü olarak bilinen "Kaleden kaleye şahin uçurdum" söz başlı türkünün "kalenin dibinde taş ben olaydım" dizesinde yine mecazi anlam yüklenerek kullanılmıştır. "Sabah olur oğlan gider işine" söz başlı türkünün "Mermer taşa sabun koydum eridi / Gügüumlere su doldurdum ılıdı" dizelerinde mermerin asıl anlamıyla kullanıldığı görülmektedir.

Tablo 21. Yapu malzemeleri

\begin{tabular}{ll}
\hline Yapı Malzemesi & f \\
\hline Taş & 5 \\
Kum & 3 \\
Toprak & 2 \\
Çimanto & 1 \\
Mermer & 1 \\
\hline
\end{tabular}

Nesneler: eşya ve araç-gereçler: Kapı (12), yöre türkülerinde asıl anlamıyla kullanıldığı gibi, içeri makamında tasavvufi anlamda da kullanılmıştır. Örneğin, “dört kapı kırk makam” gibi. "Geldi geçti kapımızdan harınan" dizesinde ise asıl anlamıla kullanılabilmektedir. 
Özellikle mektup (4), gurbetten yâre gönderilen nâme anlamındadır. Nâmede sevda ve hasretlik vardır. Tablo 22 'de yer alan ve diğer ad/adlandırma motiflerini içeren adlar, dizeleri birbirine bağlamada çok sık kullanılır. Bir diğer önemli değerlendirme ise dizelerde kullanılan eşya ve araç isimlerinin olay örgüsünü betimlemede önemli bir yer tutmasıdır. Örneğin, "Bir ay doğar ilk akşamdan geceden / Şavkı vurur pencereden bacadan" dizelerinde ayın doğuşu ve işığının yansımasının baca ve pencereye vuruşu biçimindeki betimleme gibi.

Tablo 22. Nesneler: eşya ve araç-gereçler

\begin{tabular}{llllll}
\hline Nesne & f & Nesne & f & Nesne & f \\
\hline Kapı & 12 & Çadır & 1 & Kement & 1 \\
Mektup (name) & 4 & Çekiç & 1 & Levent & 1 \\
Defter & 2 & Elek & 1 & Nal & 1 \\
Helke & 2 & Güğüm & 1 & Ok & 1 \\
Orak & 2 & Kalay & 1 & Pencere & 1 \\
Pul & 2 & Kalbur & 1 & Sapan & 1 \\
Sürgü & 2 & Kalem & 1 & Sepet & 1 \\
Baca & 1 & Kap & 1 & Sicim & 1 \\
Bakraç & 1 & Katar & 1 & Sivik & 1 \\
Balyoz & 1 & Kayık & 1 & Terazi & 1 \\
Bardak & 1 & Kazan & 1 & Tomofil (otomobil) & 1 \\
Beşik & 1 & Kazma & 1 & & \\
\hline
\end{tabular}

Sik kullanilan kelimeler-adlandırmalar: Tablo 23'te yer alan adlandırmalar için bütüncül bir değerlendirme söz konusu olamamaktadır. Çünkü türkülerde geçen birden fazla kelime-adlandırma ve nitelemeler, asıl anlamıla kullanıldığı gibi mecaz anlamlar yüklenerek de kullanılmaktadır. Kullanımlarda yar, altmış dokuz defa geçer ki bu, yöre türkülerinde aşk ve sevdalanmaya dair türkülerin ağırlıkta olduğunu gösterir. Yine gönül (40), güzel (33), aşk (17), sevdiğim (10) vb. adlandırma ve nitelendirmeler bu tespiti desteklemektedir. Bazen de kullanılan sözün tersi akla gelmelidir. Hayırsız, hayın (hain), çirkin gibi adlandırma ve nitelemeler de yârine karşı sitemkâr olup, tam tersi geçerlidir; yani çirkin dese de güzel demek istemiştir.

Tablo 23. Sik kullanılan kelimeler-adlandırmalar

\begin{tabular}{llllll}
\hline Kelime-Adlandırma & f & Kelime-Adlandırma & f & Kelime-Adlandırma & f \\
\hline Yar & 69 & Divane & 5 & Canım & 2 \\
Gönül & 40 & Gam & 5 & Güzellik & 2 \\
Dert & 34 & Gurbet & 5 & Ölürüm & 2 \\
Güzel & 33 & Sultanım & 5 & Viran & 2
\end{tabular}




\begin{tabular}{llllll} 
Dost & 29 & Yara & 5 & Acı & 1 \\
Aşk & 17 & Efendim & 4 & Biçare & 1 \\
Kul & 11 & Efkâr & 4 & Canan & 1 \\
Hasret & 10 & Hayın & 4 & Çare & 1 \\
Sevdiğim & 10 & Muhabbet & 4 & Çirkin & 1 \\
Zalım & 9 & Çile & 3 & Dertli & 1 \\
Ayrılık & 8 & Garip & 3 & Ferman & 1 \\
Aşık & 7 & Meyil & 3 & Hayırsız & 1 \\
Derman & 7 & Soysuz & 3 & Hile & 1 \\
Vefasız & 7 & Yolcu & 3 & Keder & 1 \\
Sevda & 6 & Bela & 2 & Yadeller & 1 \\
Cefa & 5 & & & & \\
\hline
\end{tabular}

Yerleşim yeri adları: Notaya alınan türkü metinlerinde Arguvan (9) isminin az geçtiği düşünülse de notaya alınmayanlara bakıldığında Arguvan, Arguvan eli vb. isim ve tamlamaların çok sık kullanıldığını görürüz. Arguvan türkülerinde gurbet önce İstanbul kadar uzakken, sonraları Almanya adıyla gurbetin uzaklığının arttığı da türkülere aktarılmıştır. Örneğin, "İstanbul değil ki gidem de gelem / Şu gurbet ellere can mı dayanır." Dizelerinde İstanbul'un gurbet olmaktan çıtı̆̆g, uzak yerlerin ise Almanya gibi işçi olarak çalışmaya gidilmiş ülkeler olduğu anlatılmıştır. Kerbela (4), Bağdat (1) ismi ise deyişlerdeki dizelerde yer alır. "Halpuz", Arguvan'da türkülerin kaynağ 1 durumundadır. Karabel; "Gelin oldum Karabel'in eline" söz başıyla başlayan ve birden çok varyantı olan bir türküde geçen yer adıdır. Yine Halpuz, Eymir, Bozan, Kızık, Mişedi Arguvan'ın köylerinden olup, Karaca ise Arguvan türkülerinin etkileşim alanında bulunan Yazıhan ilçesine bağlı bir köydür.

Tablo 24. Yerleşim yeri adları

\begin{tabular}{llllll}
\hline Yerleşim yeri & f & Yerleşim yeri & f & Yerleşim yeri & f \\
\hline Arguvan & 9 & Ankara & 1 & Karabel & 1 \\
Kerbela & 4 & Bağdat & 1 & Karaca & 1 \\
Malatya & 3 & Beylerderesi & 1 & Kayseri & 1 \\
Halpuz & 2 & Bozan & 1 & Kızık & 1 \\
Kernek & 2 & Çimanto & 1 & Mişedi & 1 \\
Adiyaman & 1 & Eymir & 1 & Şarkışla & 1 \\
Almanya & 1 & İstanbul & 1 & Yemen & 1 \\
\hline
\end{tabular}

Renk adları: Türkülerde niteleme ve adlandırmalarda renk ve sayıların çok fazla kullanıldığı görülür (Tablo 25). Kara (16), yas ve kadersizliği anlatır. Kırmızı (9) ve $A l$ (6); sevdanın, aşkın simgesidir. Sarı, hastalık 
anlamına geldiği gibi; güzelin saçını, yüz tenini, entarisini tanımlamada da kullanılmıştır. Yeşil (7); muradın, güzelliğin tanımlanmasında ek bir yardımcı renk olarak kullanıldığı gibi, inanç anlamında da önemlidir. Ela, kara ve siyah renkleri sevgilinin kaşı, saçı, göz renginin tarifinde de kullanılır. Mosmor, yemyeşil, bembeyaz, allı morlu gibi kullanımlar dizelerde anlamı sağlamlaştırmada yer almış adlandırma nitelemeleridir.

Tablo 25. Renk adlan

\begin{tabular}{llll}
\hline Renk & f & Renk & f \\
\hline Kara & 16 & Ak & 3 \\
Kırmızı & 9 & Mavi & 2 \\
Sarı & 8 & Mosmor & 2 \\
Yeşil & 7 & Allı morlu & 1 \\
Al & 6 & Beyaz & 1 \\
Ela & 4 & Bembeyaz & 1 \\
Mor & 4 & Karalı & 1 \\
Siyah & 4 & Yemyeşil & 1 \\
\hline
\end{tabular}

Hayvan adları: Türkülerde bülbül (13), kuş (9), keklik (6) gibi kuşlar dizelerde sıkça yerini almıştır. "Bülbülü tuttum da güle bağladım" dizesinde bülbülün gül ile anılmasının yanı sıra gülşen bağıla da birlikte değerlendirilmesini görebiliriz. Turna (4) kuşu ile ilgili motif incelendiğinde Alevi inancında turnanın kutsal bir kuş olarak algılandığını, sesinin $\mathrm{Hz}$. Ali'nin avazına benzetildiğini, turna donunda/biçiminde görülebildiğini öğrenmekteyiz. Bu motif özellikle deyiş ve düvazlarda görülebildiği gibi semahlarda da "Turna semahı" olarak ortaya çımaktadır. Din dışı türkülerde turna motifinin kullanımında iki temaya daha rastlanmaktadır ki gurbetten sılaya, sevgiliden yârine haber götürme görevi ile turnanın kendisiyle dertleşip/söyleşme monoloğu da dizelere yüklenmiş durumdadır. Bu da yüzyıllardır türkülerde sırdaşlık etmiş turnanın halk kültüründeki önemli bir göstergesidir (Akkuş, 2011).

Suna kuşu, yârin güzelliğinin, boyunun ince ve uzunluğunun tarifinde; mecazi olarak hem fiziki güzelliğinin hem de narinliğin, davranışlarının övülmesinde kullanılmaktadır. Keklik ise yârin yürüyüşünün, boyunun, endamının betimlenmesinde kullanılagelmiştir. Yar, bazen meri keklik gibi güzel bazen de keklik sekişli olarak tarif edilir. Şahin alıcı bir kuş olarak tarif edildiği gibi, insan adı olarak da karşımıza çıkar. Diğer önemli bir kuş motifi ise baykuştur. Baykuş çok 
güzel olmasına rağmen halk kültüründe ölümün ve harabelerin habercisi ve bekçisi olarak adlandırılır ki, "Akşam olur güneş batar / Viranda baykuşlar öter" dizesi baykuşun viran yerlerde olduğunu açıklar. Koyun, kuzu, ferik, kurt, koç, at gibi hayvan adları ise gündelik yaşamda da sıkça kullanılan hayvan ad ve adlandırmalarıdır (Tablo 26).

Tablo 26. Hayvan adları

\begin{tabular}{llll}
\hline Hayvan & f & Hayvan & f \\
\hline Bülbül & 13 & Kuzu & 2 \\
Kuş & 10 & At & 1 \\
Keklik & 6 & Ceylan & 1 \\
Arı & 4 & Gece kuşu & 1 \\
Turna & 4 & Ferik & 1 \\
Koyun & 3 & Koç & 1 \\
Suna & 3 & Kurt & 1 \\
Telli durna & 3 & Mal & 1 \\
Balık & 2 & Ördek & 1 \\
Baykuş & 2 & Şahin & 1 \\
\hline
\end{tabular}

A ̆gaç, çiçek ve bitki adları: Yörede yetişen ağaçlar da türkülerde yer almaktadır. Bu çalışmada notaya alınan türküler üzerinde inceleme yapıldığından dolayı ĭgde, çalı, karamuk, kaysı ă̆acı vb. gibi ağaç adları, diğer Arguvan türkülerinde yer almakla birlikte, bu çalışma kapsamı dışında kalmıştır (Tablo 27). Kavak, selvi/selvi kavak motifleri; yârin boyunu-posunu anlatmada kullanıldığı gibi, ulaşılması zor olan mesafeyi de betimler ki, "Selvi kavak çıkar seni budarım / geçer yamacına da seyran eylerim" dizeleri zoru başarmanın anlatılmasıdır.

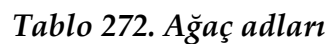

\begin{tabular}{llll}
\hline Ağaç & f & Ağaç & f \\
\hline Kavak & 3 & Selvi/Selvi Kavak & 1 \\
Çınar & 1 & Söğüt & 1 \\
Meşe & 1 & & \\
\hline
\end{tabular}

Türkülerde çiçek adları içerisinde en sık gülün (34) kullanıldığını görürüz. Yine gonca (1), goncagül (1), kırmızı gül (1) gibi tanımlamalar da gül motifiyle birlikte ele alındığında diğer çiçek adlarına karşı açık ara farkın olduğu görülür (Tablo 28). Gül, hem yar ile ilgili anlatı dizelerinde hem de deyişlerde yer alabilmektedir. İncelenen türkülerde sümbül (3), çiğdem (2), nergis (2), menekşe/mor menekşe (3), karanfil, lale gibi çiçekler de az da olsa kullanılmıştır. Yörede nevruz çiçeğinin önemli bir yeri 
olmasına rağmen çok sık kullanılmadığı gözlemlenmektedir. Çünkü yöredeki Alevi inancında nevruz ilk çıktığında, nevruzu getiren çocuğa bahşiş verilir, alınan nevruz öpülür, boynuna yüzüne sürülerek koklanır. Buradaki inanca göre, Hz. Ali Nevruz günü dünyaya gelmiştir ve Nevruzda Ali'nin kokusu vardır (Hüseyin, Şahin, 22 Mart 2018, Malatya). İ̆̆de çiçeği açtı̆̆ında burcu burcu kokar; onda yârin kokusu vardır. Yâre ulaşmak için türkünün bir dizesinde "İğde çiçeğinden dilek diledim" diyerek yâre kavuşmak için iğde çiçeğine kutsal bir anlam yüklendiği de düşünülmektedir.

Tablo 283. Çiçek ve bitki adlan

\begin{tabular}{llll}
\hline Çiçek-Bitki & f & Çiçek-Bitki & f \\
\hline Gül & 34 & İğde çiçeği & 1 \\
Çiçek & 7 & Karanfil & 1 \\
Sümbül & 3 & Kırmızı gül & 1 \\
Çiğdem & 2 & Lale & 1 \\
Menekşe & 2 & Mor menekşe & 1 \\
Nergis & 2 & Nevruz & 1 \\
Asma & 1 & Reyhan & 1 \\
Gonca & 1 & Sarı çiçek & 1 \\
Goncagül & 1 & Yonca & 1 \\
\hline
\end{tabular}

Yiyecek adları: "Kayanın dibinde mal mı yayılır / Döşeğin üstünde nar mı soyulur / Bir gün görmeyinen yar mı sevilir / Gecesi gündüzü bir olmayınca" dörtlügüünde nar meyvesi geçtiği gibi, narın halk kültüründe güzel yanağı anlattığı; bereketi, çoğalmayı simgeleyen bir motif olarak da kullanıldığı görülmektedir (Tablo 29). Yörede halay türküsü olan "Kaleden kaleye şahin uçurdum" söz başlı türküde yâre kavuşmak ve onunla konuşabilmek için verilen çaba anlatılır: "Üzüm sepetini indirdim düze / Yalvarı yaharı getirdim söze."

Elma; Arguvan halk kültürü geleneği içerisinde çok önemli bir meyve ve motif olarak görülür. Dügüne davetlerde okuntu/davetiye gönderilen kişiye elma gönderilir. Hasta yanına elma götürmek, hastaya verilen değeri gösterir. Bir yerden başka bir yere gelen olacaksa, kişi sevdiği dostuna elma ile selam gönderir. Yani al elma gönül almadır. 1970'lerin sonlarına kadar görülen adetler günümüzde önemini yitirmiştir fakat hasta yanına elma ile gitme kültürü hala devam etmektedir (Şahin, 2018). Arguvan'ın Atma yöresinde derlenen bir türküde “Biz yar olalım biz yar 
olalım / Birimiz elma birimiz nar olalım" dizelerinde yâriyle ayrı ayrı bedende olsalar da gönülde, sevdada tek yürek olmak anlatılır.

Tablo 29. Meyve-sebze adlarn

\begin{tabular}{ll}
\hline Meyve-Sebze & f \\
\hline Nar & 3 \\
Bostan & 2 \\
Elma & 2 \\
Erik & 2 \\
Üzüm & 1 \\
\hline
\end{tabular}

"Yâre şeker ezdim şerbet içirdim" dizesinin yer aldığı bir halay havasında yâre verilen önem, özellikle tatlı ile vurgulanmaktadır. Yöre ekonomisinde ve beslenmesinde önemli yeri olan süt ve süt ürünlerinin de türkülerde özellikle yâri anlatmada mecazi anlamda kullanıldığ 1 sıklıkla görülmektedir: "Şekerden, kaymaktan tatlı dili var" gibi. Arpa, yöre tarımında önemli bir üründür. Hedik ise buğdayın kaynatılmış halidir. Ekmek-tuz hakkı, kültürün önem verdiği değerlerden olup kahvenin de dostlukta hatır sayma işlevi yaygındır (Tablo 30).

Tablo 30. Diğer yiyecek adlan

\begin{tabular}{llll}
\hline Yiyecek & f & Yiyecek & f \\
\hline Bal & 6 & Arpa & 1 \\
Şerbet & 6 & Aş & 1 \\
Şeker & 5 & Ekmek & 1 \\
Yağ & 4 & Hedik & 1 \\
Kaymak & 3 & Kenger & 1 \\
Süt & 3 & Sofra & 1 \\
Kahve & 2 & Tuz & 1 \\
Yoğurt & 2 & & \\
\hline
\end{tabular}

\section{Sonuç}

Türkülerin sözel içeriksel analizleri herhangi bir yörenin sosyal ve kültürel yapısına ışık tutması bakımından oldukça önemlidir. Öyle ki türkülerin konuları, içerikleri, içerisinde geçen söylemler ve motifler; yöre halkının günlük hayatından, dini inanışlarına, coğrafi yapısından geçim kaynaklarına dair pek çok bilgiyi bünyesinde barındırır. Somut olmayan kültürel mirasın "gösteri sanatları" alanında yer alan Arguvan türkülerinin SOKÜM Ulusal Envanteri'nde kayıtlı özelliklerine bakıldığında; Arguvan'ın kültürel bir dokuya sahip olduğu 
anlaşılmaktadır. Bu doku, Alevi-Bektaşi Türkmen kültürünün ve âşıklık geleneğinin oluşturduğu bir kültürün Arguvan türkülerindeki yansıması olarak karşımıza çıkar. Dolayısıyla müzikteki bu yansıma inançsal ve dünyevi olmak üzere iki alanda belirir. Arguvan türkülerinde Hakk'ın varlık ve birliğinden söz eden tevhidler, Hz. Ali'yi ve Hz. Muhammed'i yücelten mersiyeler, Oniki imamları içeren düvazlar ve AleviBektaşiliğin geçmişten günümüze taşıdığı inançsal yaşamını konu alan semahlar ve deyişler yer alır.

Yörenin ağız yapısıyla dil özelliklerini yansıtan ve halkın gündelik yaşamının ağırlıklı olarak sevda, aşk, ayrılık, hasret, dert/sıkıntı, sitem temalarıyla anlatıldığı dünyevi türküler ise bir diğer alanı oluşturmaktadır. Bu türküler, yurt genelinde sayısal olarak en fazla bağlantıların ve katmaların yer aldığ 1 türkülerdir. İncelenen türküler içerisinde bağlantı ve katmaların oranı \%68'dir. Bu sonuç, Arguvan türkülerindeki bağlantıların ve katmaların varsıllığını doğrulamaktadır. Bir diğer önemli özellik, anlamı kuvvetlendiren tekrarların/ikilemelerin Arguvan türkülerindeki yoğunluğudur. İncelenen türkülerde kırk altı tekrar/ikileme tespit edilmiş; bunların çokluğu ve çeşitliliği, yörenin dil özelliklerini yansıtması bakımından dikkate değer bulunmuştur. Yörenin dil özelliklerini yansıtan bir başka özellik de deyim ve söylemleridir. Arguvan türkülerinde deyim ve söylemlerin çokluğu dikkat çekicidir. İncelenen türkülerin \%63'ünde deyim ve söylem bulunmaktadır. Arguvan türkülerinde geçen bağlantıların/katmaların, tekrarların/ikilemelerin, deyimlerin ve söylemlerin gerek sayısal gerek çeşitlilik açısından zenginliği, bu türkülerin SOKÜM unsuru olarak Ulusal Envantere kayıtlanmasında kendine özgü özellikleri taşıması bakımından önemlidir. Araştırma kapsamında incelenen 155 türkü bu özellikleri teyit etmektedir.

Türkülerin içeriği incelendiğinde ortaya çlkan başlıklar, Arguvan türkülerinin içerik bakımından da kendine has yapısını ortaya koymaktadır. Yöre halkı kendi yaşantısı içinde sevda, hasret, inanç, sitem gibi farklı konuları türkülerinde işlemiştir. Arguvan türkülerinde geçen özel isimler, dini unsurlar ve formülistik sayılara bakıldığında; başta Ali ve Ehl-i beyt isimleri olmak üzere, dört kapıyı temsilen dört sayısından, kırklar motifinin varsıllığına, inanç ve ritüellere dair pek çok unsur; Alevi-Bektaşi inanç kültürünün müzikteki görünümünü 
örneklemesi bakımından önemlidir. Yanı sıra, yüksek ve dağlık bir yerleşime sahip, karasal iklimin sert geçtiği Arguvan'da doğa unsuru "rüzgâr", farklı adlandırmalarla, yağan "kar"ın bile önüne geçmiştir. "Bugün", zamansal olarak içinde yaşanılan anın karşıllı̆̆ıdır. İletişimin karşı ilk durağı "göz", sevgiliyi aşk ateşine düşüren ilk organdır. Geçiş dönemlerinin en zorlusu "ölüm"dür ve kültürel bir gelenek ölümle ilintili söylemlerle bütünlenir. Çalışılan yer "bağ, bahçe"; yapı malzemesi "taş, kum"dur. Çevre betimlenirken dile getirilen "pınar", her zaman yanında bir "güzel" ile anılır. Mesafenin adı "selvi-kavak", yasın rengi "kara"dır. "Kapı" hem asıl hem tasavvufi anlamda yerini almıştır. Bu türkülerde bereket "nar", gönül alma "elma", şeker "şerbet", süt "kaymak" olmuş; "bülbül"ün aşkı "gül"den sorulmuş ve aşk "yar", sitem "gönül”, hüzün "dert", sevda "güzel", yüce "dost" ile tanımlanmıştır. Sonuç olarak, bu çalışmadaki türkülerde geçen kelimelerin özellikleri, türleri, nicelikleri; türkülerin içeriği, kültürel ögeleri, yöreye özgü kavramları, motif ve sembolleri incelendiğinde; somut olmayan kültürel miras unsuru Arguvan türkülerinin, kendine has özellikler taşıdığı anlaşılmaktadır. 
EXTENDED ABSTRACT

\title{
Content Analysis of Arguvan Folk Songs as an Intangible Cultural Heritage
}

\author{
Ülkü Akkuş- Gülşah Akkuş \\ İnönü University- İzmir Katip Çelebi University
}

Folk songs are important oral cultural data in order to analyze the social structure. They have been a melodic expression of their experiences from the past to the present in the historical process of societies. Arguvan folk songs (AFS) have a cultural difference with both the richness of the themes they deal with and the language structure. As being cultural practices, folk songs can be considered an element of intangible cultural heritage (ICH). UNESCO defines ICH as "practices, representations, expressions, knowledge, skills - as well as the instruments, objects, artifacts and cultural spaces associated" in the Convention for the Safeguarding of the ICH. In order to be included in the UNESCO ICH list for safeguarding, cultural heritage must first be added to the national list. AFS, registered with the number 01.0021 in the SOKÜM National List on March 13, 2013, has been documented as a cultural heritage element. So far, Arguvan culture and music to date, the place and position of AFS in Turkish folk music, its unique interpretation techniques, musical performance, language, and local dialect features have been researched by a limited number of scholars. This study aims to determine what the cultural characteristics of AFS are that allow it to be included in the ICH national list and to justify its inclusion in the main list. For this purpose, it has been aimed to reveal the appearance of the folk culture of the Arguvan region in folk songs by determining the characteristics and types of the words used in the folk songs, the content of the songs, the cultural elements, the local concepts, local discourses, motifs, and symbols.

A qualitative research method was applied in this research. With judgemental sampling, a total of 155 notated AFS was reached from nine different music archives, four of which were printed sources. In order to reveal the formal criteria that enabled AFS to be included in the national 
list, a content analysis was applied after the frequency analysis for the most prominent features of the folk songs (connections and additions, repetitions/duplications, idioms, and discourses). Within the scope of content analysis, first, a code list was created, and then the analyzed folk songs were classified in terms of words, meaning, and context with open coding. The concepts are counted once, no matter how many times they are repeated in a folk song. Code list consists of twenty items in total: private names; religious elements; time and seasons; elements of the sky and nature, human organs and facial features; outdoor names; transitional periods, kinship and naming; folk medicine and treatment elements; holidays, ceremonies, and beliefs; formulaic numbers; clothing, jewelry, and various accessories; construction materials; objects- goods and tools; common words - nomenclature; settlement names; color names; animal names; tree, flower and plant names; and food names.

Verbal and contextual analyzes of folk songs are very important in terms of shedding light on the social and cultural structure of any region. Considering the characteristics of AFS registered in the ICH national list; it is understood that Arguvan has a cultural texture. This texture appears as a reflection of the Alevi-Bektashi Turkmen culture and a culture formed by the minstrel tradition in AFS. Therefore, this reflection in music appears in two areas as religious and worldly. Tawhids about the existence and unity of God in AFS, elegies glorifying Hz. Ali and Hz. Muhammad, duvaz containing the Twelve imams, and semahs and sayings about the religious life of Alevi-Bektashism from the past to the present take place in AFS.

Worldly folk songs, which reflect the dialect structure and language characteristics of the region, and in which the daily life of the people are mainly told with the themes of love, love, separation, longing, trouble/distress, and reproach, constitute another area. These are the folk songs with the highest number of connections and additions throughout the country with a rate of $68 \%$. This result confirms the richness of connections and additions in AFS. Another important feature is the intensity of repetitions/duplications that strengthen the meaning in AFS. Forty-six repetitions/duplications were detected in the analyzed folk songs; their abundance and diversity have been found remarkable in terms of reflecting the language characteristics of the region. Another 
feature that reflects the language characteristics of the region is its idioms and discourses. The multiplicity of idioms and discourses in AFS is remarkable. There are idioms and discourses in $63 \%$ of the researched folk songs. The richness of the connections/additions, repetitions/duplications, idioms, and discourses in AFS, both in terms of numbers and diversity, is important in terms of having their own characteristics in registering these folk songs to the national List as an ICH element. 155 folk songs researched within the scope of this research confirm these features.

When the content of the folk songs is examined, the titles reveal the unique structure of AFS in terms of content. Local people have treated different subjects such as love, longing, faith, and reproach in their folk songs. Considering the private names, religious elements, and formulaic numbers in Arguvan folk songs; many elements related to beliefs and rituals, from the number four representing the four doors, especially the names of Ali and Ahl-i beyt, to the wealth of the forty motifs are important in terms of exemplifying the appearance of Alevi-Bektashi belief culture in music. In addition, in Arguvan, which has a high and mountainous settlement and a harsh continental climate, the element of nature "wind", with different names, has even surpassed the falling "snow". "Today" is the temporal equivalent of the moment lived in. The first stop of communication, the "eye", is the first organ that makes the lover fall into the fire of love. The most difficult of the transitional periods is "death" and a cultural tradition is integrated with discourses related to death. The place of work is "vineyard, garden"; The building material is "stone, sand". The "spring", which is mentioned when describing the environment, is always referred to with a "beautiful (woman)" next to it. The name of the distance is "cypress-poplar", the color of mourning is "black". "Door" has taken its place in both the original and mystical sense. In these folk songs, abundance became "pomegranate", atonement "apple", sugar "sorbet", milk "cream"; the love of "nightingale" was asked from "rose" and love was defined as "beloved", reproach "heart", sadness "trouble", love "beautiful", sublime "friend". As a result, in this study, when the characteristics, types, and quantities of the words, the content of the folk songs, their cultural elements, concepts specific to the region, motifs, and symbols 
are examined; it is understood that AFS, which is an ICH element, has unique characteristics.

\section{Kaynakça / References}

Akkuş, Ü. (Kasım 2011). Türkülerde turna sesi var. Uluslararası Malatya Türk Halk Müziği Sempozyumu, Malatya'da sunulan bildiri.

Akkuş, Ü., Akkuş, G. ve Andaç, F. (2014). SOKÜM bağlamında arguvan türküleri. N. Özel (Ed.) Uluslararası kültürel mirasın ve kültürel bellek kurumlarının yönetimi kongresi (s.17-20). İstanbul: Üniversite ve Araştırma Kütüphanecileri Derneği.

Akkuş, Ü. (2016). Somut olmayan kültürel mirasın korunması bağlamında arguvan türkülerinin sürdürülebilirliği. Inönü Üniversitesi Sanat ve Tasarım Dergisi, 6, 418-427.

Akkuş, Ü. ve Akkuş, G. (2018). Local female performers in publicity of arguvan folk songs, as an element of intangible cultural heritage. B. C. Tanritanır, ve S. Özer (Ed.) Academic Research In Social, Human and Administrative Sciences-I (s.391-404). Ankara: Gece Kitaplı̆̆ı.

AREGEM. (t.y.a.). Somut olmayan kültürel mirasın korunması sözleşmesi hakkında. $23 \quad$ Şubat 2018 tarihinde http://aregem.kulturturizm.gov.tr/TR,50837/somut-olmayan-kulturelmirasin-korunmasi-sozlesmesi-hak-html adresinden erişildi.

AREGEM. (t.y.b.) Somut olmayan kültürel miras ulusal envanteri. 26 Şubat 2018 tarihinde http://aregem.kulturturizm.gov.tr/TR,50840/somutolmayan-kulturel-miras-ulusal-envanteri.html adresinden erişildi.

AREGEM. (t.y.c.). Somut olmayan kültürel miras ulusal envanteri. 28 Şubat 2018 tarihinde http://aregem.kulturturizm.gov.tr/TR-159257/somutolmayan-kulturel-miras-ulusal-envanteri.html adresinden erişildi.

AREGEM. (t.y.d). Arguvan türküleri. 28 Şubat 2018 tarihinde http://aregem.ktb.gov.tr/TR-51107/arguvan-turkuleri.html_adresinden erişildi.

Arguvan ve Köyleri Eğitim Kültür Vakfı. (1998). Arguvan ezgileri- 1. İstanbul: Arguvan ve Köyleri Eğitim Kültür Vakfı.

Ataş, M. (2009). Geçmişten günümüze arguvan müzik kültürünü etkileyen faktörlerin değerlendirilmesi. Yayınlanmamış Yüksek lisans Tezi. İnönü Üniversitesi, Malatya.

Bozkurt, F. (1990). Semahlar. İstanbul: Cem Yayınevi. 
Bulgan, M. (2009). Malatya - Arguvan bölgesi saha araştırması ve etnomüzikoloji açısından önemi, Adıyaman Üniversitesi Sosyal Bilimler Enstitüsü Dergisi, 2(2), 49-53.

Coşar, M. (2011). Alevi - Bektaşi kültüründe sayılara yüklenen terim değeri. Türk Kültürü ve Hacı Bektaşi Veli Araştırma Dergisi, 60, 113-128.

Eroğlu, S. (2011). Arguvan Yöresinde İcra Edilen Semahlarm Müzikal Analizi. Yayınlanmamış Yüksek Lisans Tezi, İTÜ, İstanbul.

Günşen, A. (2007). Gizli dil açısından Alevilik - Bektaşilik erkan ve deyimlerine bir bakış. Türkoloji Araştırmaları Dergisi, 2(2), 328-350.

Haşhaş, S., İmik, Ü. ve Aydoğdu, C. (2015). Malatya/Arguvan halk müziği kültürü üzerine bir araştırma. Turkish Culture \& Haci Bektas Veli Research Quarterly, 75, 201-213.

Oğuz, M. Ö. (2009). Somut olmayan kültürel miras ve kültürel ifade çeşitliliği. Milli Folklor, 21(82), 6-12.

Oğuz, M. Ö. (2013). Somut olmayan kültürel miras nedir? (2. Baskı). Ankara: Geleneksel Yayıncilı.

Öztelli, C. (1972). Evlerinin önü-halk türküleri. İstanbul: Hürriyet Yayınları.

Saz Kursu (t.y.) 26 Şubat 2018 tarihinde http://wwww.sazkursu.com adresinden erişildi.

Sert, F. (2017). Elazığ Harput türküleri üzerine bir inceleme. Ana Dili Ĕ̆itimi Dergisi-Journal of Mother Tongue Education, 5(1), 65-86.

Şahin, H. (2017). Arguvanlı Ozan Abbas Ekici, mezarımın İşareti Kırmızı, YaşamıSanatt-Şiir ve Türküleri. Malatya: Protech Matbaa.

Şahin, H., ve Özerol, S. (2004). Arguvan Türküleri / Halkbilimsel Bir Araştırma Denemesi. İstanbul: Arguvan ve Köyleri Eğitim Kültür Vakfı Yayınları.

Temiz, M. (1998). Arguvan ezgileri- 2. İstanbul: Arguvan ve Köyleri Eğitim Kültür Vakfı.

TRT Nota Arşivi (t.y.) 26 Şubat 2018 tarihinde http://www.trtnotaarsivi.com/thm.php adresinden erişildi.

Türk Müzik Kültürünün Hafızası (t.y.) 26 Şubat 2018 tarihinde http://wwww.sanatmuziginotalari.com/thm adresinden erişildi.

Türkü Dostları (t.y.) 26 Şubat 2018 tarihinde https://notalar.turkudostlari.net adresinden erişildi.

Ufuk Erbaş (t.y.) 26 Şubat 2018 tarihinde https://ufukerbas.files.wordpress.com adresinden erişildi. 
UNESCO. (2003). Somut olmayan kültürel mirasın korunması sözleşmesi. 23 Şubat 2018 tarihinde https://ich.unesco.org/doc/src/00009-TR-PDF.pdf adresinden erişildi.

UNESCO (t.y.) UNESCO Türkiye Milli Komisyonu, somut olmayan kültürel miras (SOKÜM) ihtisas komitesi raporu. 23 Şubat 2018 tarihinde http://www.unesco.org.tr/Content Files/Content/Sektor/Kultur/sokum bb.p df adresinden erişildi.

Vural F. G. ve Vural, T. (2013). Niğde kültürünün sesi: Niğde türküleri. International Periodical for The Languages, Literature and History of Turkish or Turkic, 8(3), 645-657.

Yıldırım, A. ve Şimşek, H. (2013). Sosyal Bilimlerde nitel araştırma yöntemleri. Ankara: Seçkin Yayıncilık.

Yücel, H. (2016). Merzifon'un kültürel mirası: Merzifon türküleri. Uluslararası Sosyal Araştırmalar Dergisi, 9(42), 409-418.

\section{Kaynakça Bilgisi / Citation Information}

Akkuş, Ü. ve Akkuş, G. (2021). Somut olmayan kültürel miras kapsaminda Arguvan türkülerinin içerik analizi. OPUSUluslararası Toplum Araştırmaları Dergisi, 18(42), 5907-5941. DOI: 10.26466/opus.817644. 